\title{
Role of Suspended Sediments and Mixing in Reducing Photoinhibition in the Bloom-Forming Cyanobacterium Microcystis
}

\author{
Justin D. Chaffin, Thomas B. Bridgeman, Scott A. Heckathorn, Ann E. Krause \\ Lake Erie Center, Department Environmental Sciences, University of Toledo, Oregon, USA \\ Email: justin.chaffin@rockets.utoledo.edu
}

Received October 2, 2012; revised November 4, 2012; accepted November 15, 2012

\begin{abstract}
Toxic cyanobacterial blooms are becoming a global problem. Previous research of cyanobacterial bloom development has examined how high nutrient concentrations promote cyanobacteria dominance, and how positive buoyancy provides an ecological advantage over sinking phytoplankton. Tributaries responsible for loading nutrients into lakes often simultaneously contribute high concentrations of suspended sediments. High concentrations of suspended sediments may also influence blooms by affecting the ambient light climate, reducing photodamage, and increasing the efficiency of photosynthesis. We examined the effects of sediments and vertical mixing in potentially reducing photodamage to $\mathrm{Mi}$ crocystis by measuring photosynthetic parameters and pigment content of Microcystis in western Lake Erie during the 2008 bloom and in laboratory experiments. Photosynthetic efficiency increased with increasing sediment concentration in the lake and laboratory experiment. Content of photo-protective carotenoid pigments per dry weight decreased with increasing sediment concentrations, while the light-harvesting pigments, chl $a$ and phycocyanin, increased with sediments. These results indicate that suspended sediments reduce photoinhibition for Microcystis. Further, photosynthetic damage was higher when Microcystis was concentrated on the surface compared to a mixed water column. Measurements of Microcystis abundance and light were also recorded, in addition to photosynthetic measurements. Greatest Microcystis abundances in Lake Erie were recorded during light-limiting conditions, which offer Microcystis both physiological and ecological benefits by reducing photoinhibition and increasing Microcystis' advantage in light competition via buoyancy. Efforts to reduce cyanobacterial blooms may include reducing suspended sediments loads in combination with reducing nutrient loading.
\end{abstract}

Keywords: Chlorophyll Fluorescence; Cyanobacteria; Harmful Algae Bloom; Lake Erie; Microcystis; Suspended Sediments

\section{Introduction}

High biomasses of cyanobacteria, often called "blooms", are one of the foremost problems facing the protection of water quality [1]. Cyanobacterial blooms are a concern due to their toxins that affect aquatic animals, livestock, and humans [2], and negatively impact local economies [3]. Cyanobacterial blooms have become a global problem as a result of excess inputs of anthropogenic nutriaents [4]. Research devoted to the development of cyanobacterial blooms has been focused on high nutrient concentration, especially phosphorus $(\mathrm{P})$ and nitrogen $(\mathrm{N})$ $[5,6]$, low N-to-P ratios [7], water column stability $[8,9]$, global climate change [10,11], and Dreissena mussel selective rejection [12]. Tributaries that are often responsible for high nutrient concentrations in the adjacent waters of lakes may simultaneously contribute high concentrations of suspended sediments $[13,14]$. The impacts of high suspended sediments on zooplankton, fish, and benthic invertebrates is well known [15]. However, the effect of suspended sediments on cyanobacterial bloom development, specifically Microcystis spp., is less understood.

Suspended sediments increase the rate at which light is attenuated with depth in aquatic ecosystems, as does high phytoplankton abundance and dissolved organic compounds [16]. Light attenuation affects photosynthesis as phytoplankton acclimate to changes in light intensity in time scales of seconds to days by altering their pigment composition and photosynthetic rates [17]. High attenuation results in less phytoplankton biomass due to lightlimited conditions [18], favoring cyanobacteria that can regulate their vertical position in the water column and remain in the photic zone. For example, the highlybuoyant cyanobacterium Microcystis [9] can accumulate 
high biomasses at the surface of a lake (often called a "surface scum") during periods of calm winds, no precipitation, and high atmospheric pressure [19]. Surface scums can be exposed to high-light intensities for prolonged lengths of time, damaging photosynthetic machinery [20]. However, buoyancy only allows Microcystis to form surface scums when the upward migration rate exceeds the turbulent mixing of the water column [21]. Wind speeds greater than $3 \mathrm{~m} \cdot \mathrm{s}^{-1}$ will break up a surface scum $[19,22,23]$ and also circulate negatively buoyant phytoplankton species into the photic zone, thus negating the advantage of buoyancy regulation [9]. Previous research has shown that vertical mixing of the water column provides relief from high-light intensities by circulating Microcystis to deeper depths [24,25]. Furthermore, river-generated sediment plumes increase phytoplankton primary production [26]. However, there is currently a poor understanding of how the interaction between mixing of the water column and sediment plumes affects Microcystis bloom formation.

Suspended sediments and nutrient concentrations often co-vary in nearshore zones. In this manuscript we isolate the effects of suspended sediments from the effects of nutrients on the photosynthetic status of Microcystis blooms in western Lake Erie and in laboratory experiments. In another report, Chaffin et al. [27], analyzed the nutrient status of the samples collected for this manuscript and showed that all were N-replete while the majority of samples had a moderate P deficiency. Sediments are loaded into Lake Erie from the Maumee River at the rate of 800 tonnes per day [14] and the concentrations of suspended sediments decreases from nearshore to offshore [28], which makes western Lake Erie an ideal location to study the effects of suspended sediments on Microcystis bloom development. Furthermore, the spatial pattern of Microcystis blooms in western Lake Erie closely aligns with the Maumee River sediment plume [27]. We use physiological measurements (chlorophyll fluorescence and pigment content) as tools to determine Microcystis's photosynthetic status in response to the difference of light intensity between sediment plume water and clear water, and between calm water and mixed water. We hypothesized that Microcystis surface scums will be more photo-inhibited than Microcystis in a mixed water column. We also hypothesized that high concentrations of suspended sediments not only give buoyant Microcystis an ecological advantage for light competition, but also create a more favorable light climate for photosynthesis, providing a physiological benefit.

\section{Materials and Methods}

\subsection{Study Site}

The Maumee River drains a large $\left(16,376 \mathrm{~km}^{2}\right)$ agricul- tural (87.8\%) watershed [29] that empties into the western corner of Lake Erie (Figure 1). The high sediment load from the river [14] results in a steep gradient of high suspended sediments and nutrient concentrations from the Maumee River mouth to offshore Western Lake Erie [28]. Further, the shallowness of Maumee Bay $(<2 \mathrm{~m})$ and the western basin (mean depth of $7.4 \mathrm{~m}$ ) allows for frequent wind-induced sediment re-suspension from the lake bottom [30]. Although a persistent summer thermocline does not develop in western Lake Erie, diurnal stratification is common [31]. However on calm days diurnal thermal stratification $\left(1^{\circ} \mathrm{C}\right.$ difference between surface to bottom water) can suppress water column mixing [32]. Longer calm periods may lead to episodic $\left(>2^{\circ} \mathrm{C}\right)$ thermal stratification for periods ranging from 2 to 10 days [33]. Microcystis has an ecological advantage during the periods of stratification [9], but also is exposed to high-light intensity that may cause photoinhibition.

Microcystis spp. blooms have become an annual occurrence in western Lake Erie in recent years [34]. The spatial pattern of the blooms closely coincides with the near-shore suspended sediment plume [27,28], which suggests conditions in the plume promote Microcystis blooms. In the sediment plumes total $\mathrm{P}$ can reach concentrations greater than $5 \mu \mathrm{mol} \cdot \mathrm{L}^{-1}$ and secchi disk depths are less than $50 \mathrm{~cm}$ due to high suspended sediments [27].

The light attenuation coefficient $\left(\mathrm{k}_{\mathrm{d}}\right)$ was used as a proxy for suspended sediments. Both suspended sediments and phytoplankton can influence the $\mathrm{k}_{\mathrm{d}}$ measurements. In Maumee Bay and western Lake Erie, however, suspended inorganic particles are the major factor in reducing water clarity $[28,30]$. Past measurements of suspended sediments (as non-volatile suspended solids (NVSS)) at our sample sites indicate that suspended sediments can be predicted from $\mathrm{k}_{\mathrm{d}}$ (NVSS $\mathrm{mg} \cdot \mathrm{L}^{-1}=$ $\left(12.936 \times \mathrm{k}_{\mathrm{d}}\right)-11.244 ; \mathrm{N}=52, p<0.001, r^{2}=0.87$, Bridgeman unpublished data). There was no relationship between $\mathrm{k}_{\mathrm{d}}$ and chlorophyll $a\left(p=0.671, r^{2}=0.004\right.$, Bridgeman unpublished data). Therefore, we use $k_{d}$ as an index of suspended sediment concentration.

\subsection{Limnological Measurements and Microcystis Collection}

In this report, we refer to the Microcystis spp. community collectively as Microcystis. Microcystis aeruginosa makes up the majority of the Microcystis population in Lake Erie, but other species may be present [35]. Collections and measurements were made at six sites along an approximately $80 \mathrm{~km}$ route in western Lake Erie and in Maumee Bay (Figure 1) on ten dates from 7 July to 25 September 2008, approximately once every 14 days. All 


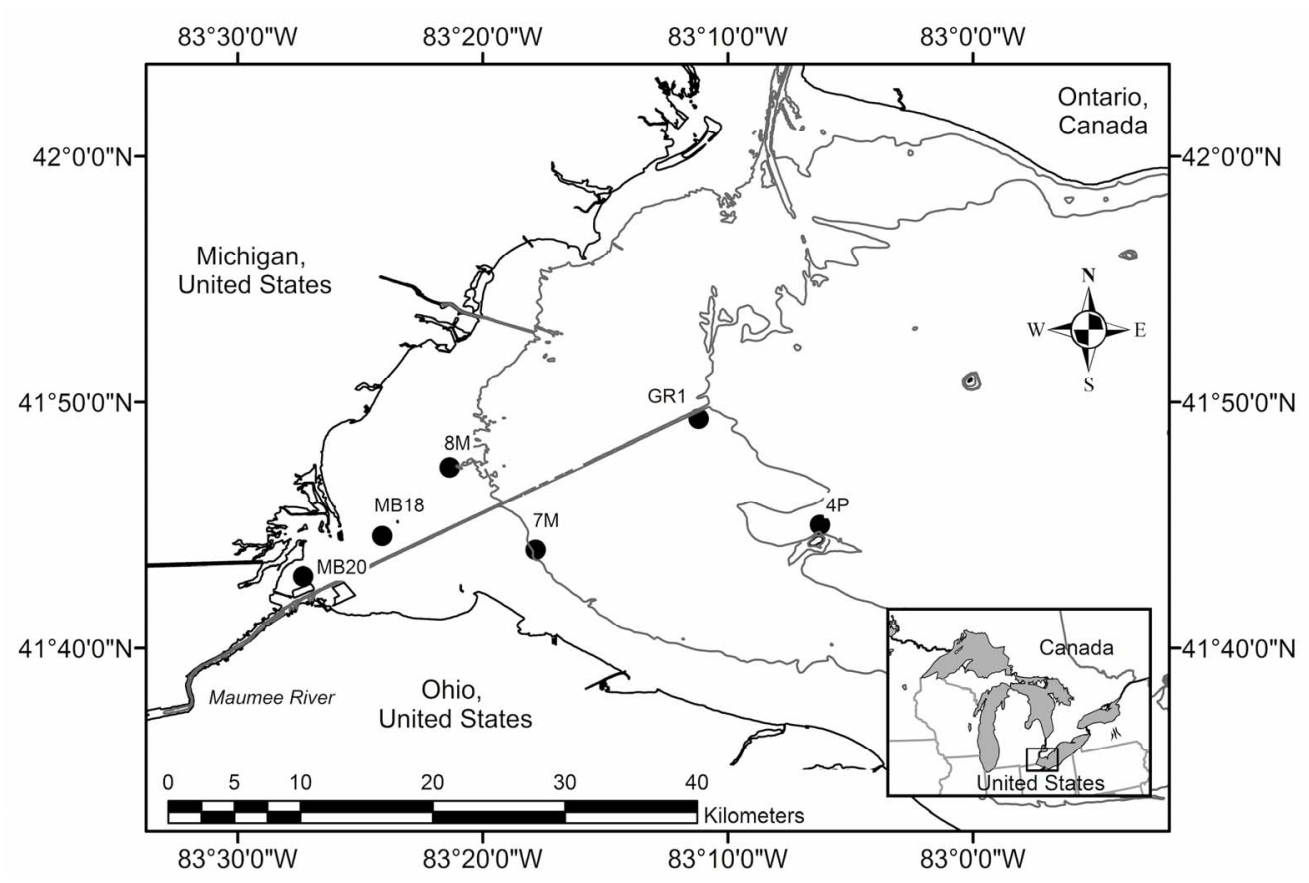

Figure 1. Sample locations in western Lake Erie. Contour lines are 5 meters and 9 meters. Site GR1 is located near the end of a dredged shipping channel.

collections and field measurements were recorded between 10:00 am to 3:00 pm on full-sun days. At each site, Microcystis abundance was estimated by the biovolume retained in vertical plankton tow samples using a $112 \mu \mathrm{m}$ mesh net as a part of a long-term study of Microcystis abundance in western Lake Erie [27]. For photosynthetic and pigment content measurements to be made in the laboratory, Microcystis was collected from the lake using a $64 \mu \mathrm{m}$ net, which captures $99 \%$ of Microcystis cells [27]. The Microcystis collected was stored in dark polyethylene bottles at ambient lake temperature during transportation back to the laboratory. Depending on sample location, two to six hours passed between collection on the lake and laboratory analysis. Upon arriving at the laboratory, Microcystis was separated from other plankton via buoyancy separation in Imhoff cones [27] and examined for the presence of other phytoplankton species by microscopy. These separated net samples were nearly $100 \%$ Microcystis, with exception of a trace amount of Anabaena 24 July and 6 August.

Vertical profiles of water temperature, $\mathrm{pH}$, and dissolved oxygen were recorded using a YSI \#6600 probe (Yellow Springs Instruments, Yellow Springs, OH, USA). Wind speed and direction were measured approximately $2 \mathrm{~m}$ above the surface of the water using a hand-held anemometer (Kestrel \#1000, Birmingham, MI, USA) integrated over 15 seconds. Underwater photon flux density PAR (Li-Cor \# LI - 188B with spherical sensor, Lincoln, NE, USA) was recorded at every half-meter from surface to 2 meters and at every one-meter from 2 meters to 5 meters, or at quarter-meter intervals in highly turbid water. Light attenuation coefficients of PAR $\left(\mathrm{k}_{\mathrm{d}}\right)$ were calculated as the linear regression slope of the natural log of PAR vs depth [16]. The depth of the photic zone was determined as the depth where light intensity was $1 \%$ of that surface light intensity. Vertical position of phytoplankton and Microcystis was determined by chl $a$ and phycocyanin (PC) concentration from lake water collected at surface, $1 \mathrm{~m}, 3 \mathrm{~m}$, and $5 \mathrm{~m}$ using a Van Dorn bottle (see methods below).

\subsection{Photosynthetic Parameters of Lake Samples}

In this section, we made photosynthetic measurements aboard the research vessel and collected samples for additional photosynthetic measurements to be made in the laboratory. Photosynthetic efficiency was measured as the quantum yield of photosystem II (PSII) electron transport $\left(\Phi_{\mathrm{et}}\right)$. PSII is often the weak link of photosynthetic electron transport, as it is most vulnerable to light-induced damage, i.e. photoinhibition [36]. $\Phi_{\text {et }}$ naturally decreases with increased light intensity, but decreases in $\Phi_{\text {et }}$ at a given light intensity indicate either damage to PSII or post PSII electron transport, or photoprotective down-regulation of electron transport [37]. $\Phi_{\mathrm{et}}$ is proportional to carbon fixation at a given light level [38]. Onboard, $\Phi_{\text {et }}$ of the whole phytoplankton community was measured on phytoplankton collected at the surface and at $1 \mathrm{~m}$ depth for sample dates after 24 July -when Microcystis was present. Water was collected 
using a Van Dorn bottle, transferred to dark polyethylene bottles, and immediately filtered through Whatman GF/C filters or Fisher Brand G4 filters (1.2 $\mu \mathrm{m}$ pore sizes) [39] using low vacuum pressure $(<10 \mathrm{~cm} \mathrm{Hg})$. Approximately 20 to $50 \mathrm{~mL}$ of water was used per filter. Filtering and measuring of $\Phi_{\text {et }}$ took place in the boat's cabin to avoid direct sunlight. The $\Phi_{\text {et }}$ of phytoplankton was determined within 60 seconds from collection, using an OS1-FL OptiSciences modulated fluorometer (Hudson, NH, USA).

In the laboratory, light-response (PI) curves and the maximal PSII quantum yield $\left(F_{\mathrm{v}} / F_{\mathrm{m}}\right)$ measurements were made with Microcystis collected from the lake. PI curves were generated by measuring $\Phi_{\mathrm{et}}$ at nine light intensities from 20 to $1640 \mu \mathrm{mol}$ photons $\mathrm{m}^{-2} \cdot \mathrm{s}^{-1}$ using a Walz fluorometer (model PAM 101/103, Effeltrich, Germany) and light pulse provided by a Schott flash lamp (model KL1500, Elmsford, NY, USA) [40,41]. The relative electron transport rate (rETR) was calculated from $\Phi_{\text {et }}$ and light intensity [42]: $\mathrm{rETR}=\Phi_{\mathrm{et}} \times \mathrm{PAR} \times$ absorbance constant, PAR is the light intensity, and 0.85 was assumed to be the absorbance constant. The PI curve data were fit to the equation of Zhang et al. [43], and then the maximum $\mathrm{rETR}\left(\mathrm{rETR}_{\max }\right)$ was calculated. $F_{\mathrm{v}} / F_{\mathrm{m}}$ was determined on separate samples that had been dark-acclimated for 30 minutes [42]. Decreases in dark $F_{\mathrm{v}} / F_{\mathrm{m}}$ indicate damage to PSII. Even though the fluorometers used here were designed for plants, they have been used for cyanobacteria and have been shown to positively correlate with net photosynthesis of cyanobacteria [40]. For further description of the chlorophyll fluorescence parameters, please see Schreiber et al. [42], Campbell et al. [40], or Maxwell and Johnson [36].

\subsection{Pigment Content of Lake Samples}

To determine the ability of Microcystis to alter photosynthetic pigment content (also to assist in interrupting the photosynthetic fluorescence data, see Discussion), chl $a, \mathrm{PC}$, and total carotenoid content were determined on Microcystis collected from the lake. Microcystis was separated in Imhoff cones (as above), concentrated, and then stored at $-80^{\circ} \mathrm{C}$ until analysis. Photosynthetic pigments were extracted from still-frozen Microcystis. Chl $a$ and total carotenoid were extracted in dimethyl sulfoxide heated to $70^{\circ} \mathrm{C}$ for 45 minutes, then centrifuged at 21,000 $g$ for 10 minutes to remove debris. Chl $a$ and total carotenoid were calculated from absorbance read using a UV 1650 PC Shimadzu (Columbia, MD, USA) spectrophotometer [44]. Total carotenoid are presented relative to chl a. PC was extracted in $0.1 \mathrm{M}$ sodium phosphate buffer pH 6.8 [45] with cells lysed by sonication (Bransonic \#1510, Danbury, CT, USA) in an ice bath for 15 minutes. Samples were incubated at $4{ }^{\circ} \mathrm{C}$ for 60 minutes and then centrifuged for 10 minutes at $4600 \mathrm{~g}$. PC fluo- rescence was recorded in a 10 - AU Turner Design fluorometer (Sunnyvale, CA, USA) with P/N $10-305$ filters. $\mathrm{PC}$ was quantified using a standard curve of C-PC standards. Pigment content was corrected for dry weight (mg of pigment per $\mathrm{g}$ of dry weight tissue) determined by drying tissue until a constant weight at $70^{\circ} \mathrm{C}$. Dry weight was constant after 24 hours.

\subsection{Laboratory Experiment}

Suspended sediment concentration and nutrients often co-vary, and each may potentially affect photosynthesis. Water column mixing might also generate suspended sediments in shallow lakes, possibly producing another interaction effect. To isolate the effects of suspended sediments, nutrients, and mixing, a $2 \times 2 \times 2 \times 2$ factorial experiment was used to test the effects of nutrient concentration (low and high nutrients), suspended sediments (low and high), mixing (mixed or non-mixing), and sample depth (surface and at depth) on photosynthetic efficiency and pigments. All six treatment combinations (nutrient $\times$ suspended sediments $\times$ mixing) were randomized between trials and samples were collected from both depth in each trial. The experiment was replicated in three independent trials, with each treatment combination in each trial. Experimental tanks were constructed of 61 $\times 9 \times 90 \mathrm{~cm}(36.5 \mathrm{~L})$ polyethylene bins. Experiments were conducted in a greenhouse and exposed to natural sunlight (up to $1500 \mu \mathrm{mol}$ photons $\mathrm{m}^{-2} \cdot \mathrm{s}^{-1}$ ) at ambient temperature $\left(25^{\circ} \mathrm{C}-28^{\circ} \mathrm{C}\right)$.

De-chlorinated water was used for this experiment. Mixing of the chamber was achieved using powerhead pumps (Aquatic gardens \#601, San Diego CA, USA), so that the intake hose was placed at the bottom of the chamber and outflow just beneath the surface. Suspended sediments and nutrient treatments were chosen to reflect conditions in Maumee Bay (high sediments and high nutrients) and the center of the western basin (low sediments and low nutrients). Sieved $(400 \mu \mathrm{m})$ Lake Erie top-layer $(0-2 \mathrm{~cm})$ sediments were added to bring the high sediment level to $30 \mathrm{NTU}$ and low sediment level was 1 NTU. After sediments were added, sodium nitrate and sodium phosphate were added to bring the initial concentration up to $215 \mu \mathrm{mol} \mathrm{N} \mathrm{L} \mathrm{L}^{-1}$ and $4.85 \mu \mathrm{mol} \mathrm{P} \mathrm{L}{ }^{-1}$ for the high nutrient and $43 \mu \mathrm{mol} \mathrm{N} \mathrm{L} \mathrm{L}^{-1}$ and $0.97 \mu \mathrm{mol} \mathrm{P}$ $\mathrm{L}^{-1}$ for the low nutrient treatment, which reflect Maumee Bay and offshore western basin, respectively [27]. All other nutrients were at half concentration of the WC medium [46] and were the same among all experimental treatments. Cultures of Microcystis with a know chl $a$ level were added so that each chamber had an initial chl $a$ of $2.5 \mu \mathrm{g} \cdot \mathrm{L}^{-1}$. Microcystis that was intended for the experiment were grown in separate liquid cultures with the nutrient concentration of the low treatment level for 
two weeks before use in the experiment, to insure that internal phosphorus storage did not take place. This $\mathrm{Mi}$ crocystis was collected from Lake Erie during 2008 and cultured in laboratory.

Once treatments were set up and Microcystis added, 96 hours were allowed for growth. Following the 96 hours, samples were collected at the surface and at a depth of 70 $\mathrm{cm}$. At $70 \mathrm{~cm}$, light levels in the low-sediment treatment were approximately $20 \%$ of surface light (measured just beneath water surface). In the high-sediment treatment, light levels at $70 \mathrm{~cm}$ were $<0.5 \%$ of the surface irradiance. At the end of the incubation period, $100 \mathrm{~mL}$ of water containing phytoplankton was filtered onto GF/F filters and $\Phi_{\text {et }}$ was measured within 60 seconds after collection. Separate samples were dark-acclimated for $30 \mathrm{~min}$ utes and $F_{\mathrm{v}} / F_{\mathrm{m}}$ was determined. $\Phi_{\mathrm{et}}$ and $F_{\mathrm{v}} / F_{\mathrm{m}}$ were determined on filters as above. Chl $a$ and total carotenoid concentration were determined on the filters as above. Photosynthetic measurements and light levels were recorded between 12:00 pm and 2:00 pm on sunny days.

\subsection{Data Analysis}

Past studies of cyanobacteria surface scum formation [19] classified the presence or absence of a surface scum based on visual observations of cyanobacterial colonies at the surface. In this study, we attempt to determine if a surface scum is present or absent based on quantitative measurements of wind speed, water temperature profiles, and phytoplankton vertical position (Table 1). Water temperature profiles are often used to separate the epilimnion from the hypolimnion; however, western Lake Erie usually lacks thermal stratification. The concentration of photosynthetic pigments (chl $a$ and PC) at the surface relative to 1 meter allows determination of how much of the phytoplankton is concentrated at the surface (hence a surface scum). PC concentration gives insights to how much of the chl $a$ is due to Microcystis. Samples that were collected when Microcystis was concentrated at the surface (low wind speed, high ratio of surface: 1 meter pigment concentration) were classified as a "surface scum", while samples collected when Microcystis was circulated down to deeper depths (high wind speeds, low ratios of surface: 1 meter pigments) were classified as "mixed".

To determine the effects of suspended sediments, vertical mixing of the water column, and depth on the phytoplankton community in situ $\Phi_{\mathrm{et}}(\mathrm{n}=59)$, ANCOVA models were used to tests for the effects of depth ( 0 meter, 1 meter), mixing (surface scum or mixed), and suspended sediments $\left(\mathrm{k}_{\mathrm{d}}\right.$, range: 0.44 to $\left.4.83 \mathrm{~m}^{-1}\right)$ on $\Phi_{\mathrm{et}}$. Statistics were computed using PROC REG of the statistical software $\mathrm{SAS}^{\circledR}$ (v. 9.1, Cary, NC, USA) by converting our categorical factors (depth, mixing) into indicator variables [47] and $\mathrm{k}_{\mathrm{d}}$ was the covariate. Significance was determined with $\alpha=0.05$ for all tests.

The effect of suspended sediments on photosynthetic parameters measured from the PI curve, $F_{\mathrm{v}} / F_{\mathrm{m}}$, and pigments (chl $a, \mathrm{PC}$, total carotenoid:chl $a$ ) was analyzed using linear regressions vs $\mathrm{k}_{\mathrm{d}}$. Surface scums and mixed samples were analyzed separately because ANCOVA test for parallel slopes indicated that slopes were not parallel for all parameters, hence not appropriate for $\mathrm{AN}$ COVA test.

For the laboratory experiment, four-way ANOVAs were performed to test for the effect of mixing (mixed or calm), sediments (high or low), nutrients (high or low), and sample depth (surface and at depth) on $\Phi_{\mathrm{et}}, F_{\mathrm{v}} / F_{\mathrm{m}}$, and total carotenoid:chl $a$. Tukey HSD test was performed for multiple comparisons. PROC GLM of SAS ${ }^{\circledR}$ was used [47].

Table 1. Classification of "surface scum" or "mixed" conditions based on wind speed, chlorophyll (chl) $a$, and phycocyanin (PC) profiles. Surface:1 meter is the ratio of chl $a$ or PC measured at the surface relative to chl $a$ or PC measured at 1 meter. Values greater than 1 indicate that phytoplankton is concentrated at the surface. PC: $\mathrm{Chl} a$ is the ratio of PC to Chl $a$ averaged across all six sites and depths. Values are averages $( \pm \mathrm{SE})$ across 6 sample sites.

\begin{tabular}{|c|c|c|c|c|c|c|}
\hline \multirow{2}{*}{ Surface Scum } & July 24 & August 6 & August 12 & August 21 & September 1 & September 25 \\
\hline & Mixed & Present & Present & Mixed & Mixed & Present \\
\hline $\begin{array}{l}\text { Wind Speed } \\
\left(\mathrm{m} \cdot \mathrm{s}^{-1}\right)\end{array}$ & $3.83 \pm 0.38$ & $1.28 \pm 0.30$ & $1.62 \pm 0.25$ & $3.90 \pm 0.19$ & $3.62 \pm 0.29$ & $1.73 \pm 0.43$ \\
\hline $\begin{array}{l}\text { Surface Chl } a \\
\quad\left(\mu \mathrm{g} \cdot \mathrm{L}^{-1}\right)\end{array}$ & $15.42 \pm 10.4$ & $38.47 \pm 18.2$ & $28.52 \pm 15.6$ & $15.24 \pm 2.9$ & $31.80 \pm 2.1$ & $227.17 \pm 176.0$ \\
\hline $\begin{array}{l}\text { Surface Chl } a: 1 \mathrm{~m} \\
\text { Chl } a\end{array}$ & $1.00 \pm 0.05$ & $1.81 \pm 0.61$ & $3.02 \pm 1.96$ & $0.99 \pm 0.03$ & $1.07 \pm 0.07$ & $6.95 \pm 4.99$ \\
\hline $\begin{array}{l}\text { Surface PC } \\
\left(\mu \mathrm{g} \cdot \mathrm{L}^{-1}\right)\end{array}$ & $0.38 \pm 0.2$ & $35.25 \pm 18.1$ & $46.47 \pm 39.9$ & $14.63 \pm 5.4$ & $22.67 \pm 3.5$ & $89.04 \pm 66.2$ \\
\hline Surface PC: $1 \mathrm{~m} \mathrm{PC}$ & $1.38 \pm 0.21$ & $5.31 \pm 2.63$ & $9.70 \pm 8.11$ & $1.51 \pm 0.08$ & $1.04 \pm 0.08$ & $17.41 \pm 11.35$ \\
\hline PC:Chl $a$ & $0.03 \pm 0.01$ & $0.47 \pm 0.17$ & $0.97 \pm 0.45$ & $0.67 \pm 0.15$ & $0.66 \pm 0.07$ & $0.33 \pm 0.09$ \\
\hline
\end{tabular}




\section{Results}

\subsection{Lake Properties}

Figure 2 displays Microcystis abundance, light availability, and water temperature in western Lake Erie during 2008. Microcystis was absent from net tows until 24 July, and during this time the photic depth to lake depth ratio was greater than 0.5 , indicating a high-light environment. Between 12 August and 21 August Microcystis biovolume retained in nets increased nearly four-fold and remained high for the rest of the summer. On 21 August through rest of summer, the photic depth to lake depth ratio was less than 0.2 . Water temperature was between $22^{\circ} \mathrm{C}$ and $26^{\circ} \mathrm{C}$ during the Microcystis bloom. Dissolved oxygen (DO) ranged from 7.6 to $10.2\left(\mathrm{mg} \cdot \mathrm{L}^{-1}\right)$ and $\mathrm{pH}$ from 8.0 to 8.6 from measurements at 1 meter depth at all sites and dates. DO and $\mathrm{pH}$ did not vary with depth except on 6 August when there was a $1.1 \mathrm{mg} \cdot \mathrm{L}^{-1}$ difference in $\mathrm{DO}$ and $0.5 \mathrm{in} \mathrm{pH}$ between surface and near sediments at stratified sites. $\mathrm{k}_{\mathrm{d}}$ was relatively low from June to mid August at all sites except MB20- the site closest to the Maumee River (Figure 3). Much higher $\mathrm{k}_{\mathrm{d}}$ was recorded following mid August. On each sample date, there was a general pattern with highest $\mathrm{k}_{\mathrm{d}}$ measured in Maumee Bay (sites MB20 and MB18), and lower $\mathrm{k}_{\mathrm{d}}$ further from shore (sites GR1 and 4P).

Thermal stratification was only observed on 6 August, with $2^{\circ} \mathrm{C}$ difference between the surface and bottom waters. Wind speed, chl $a$, and PC concentration were used to classify each sample date as surface scum or mixed

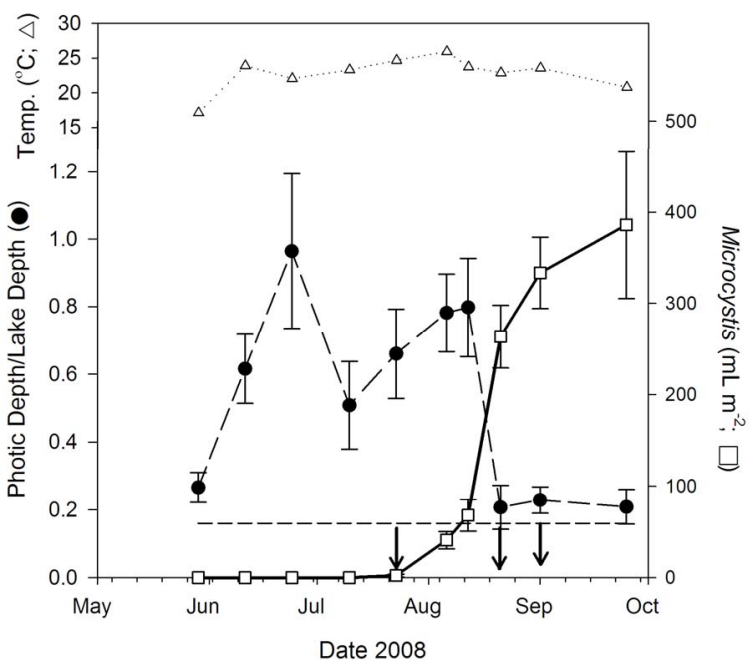

Figure 2. Light availability as photic depth/lake depth (dashed line; filled circles), temperature (dotted line; open triangles) and Microcystis biovolume (bold line; open squares) in western Lake Erie during 2008. Arrows represent sample dates with mixed conditions. The horizontal dashed line with no symbols corresponds to 0.16 , the value that indicates light limitation of phytoplankton biomass [18]. Values are the mean $( \pm \mathrm{SE})$ of six sites.

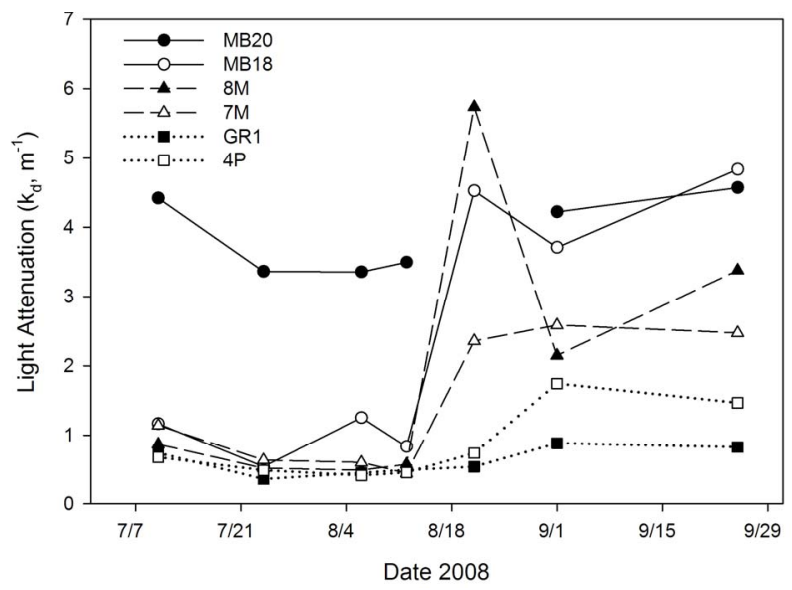

Figure 3. Light attenuation coefficients $\left(k_{d}\right)$ recorded in western Lake Erie at 6 locations during summer 2008. Site MB20 was not sampled on 21 August.

(Table 1). Microcystis was concentrated as a surface scum on 6 August, 12 August, and 25 September. On these dates, wind speeds were less than $1.73 \mathrm{~m} \cdot \mathrm{s}^{-1}$, which allowed Microcystis to float and become concentrated on the surface as indicated by high surface chl $a-1$ meter chl $a$ ratios. Therefore, 6 August, 12 August, and 25 September were classified as "surface scum" dates. Wind speeds greater then $3.62 \mathrm{~m} \cdot \mathrm{s}^{-1}$ on 24 July, 21 August, and 1 September resulted in the Microcystis mixing down to deeper depths preventing a surface scum. Surface chl $a$ and PC concentrations were nearly identical to chl $a$ and PC concentrations measured at 1 meter and half-watercolumn-depth. 24 July, 21 August, and 1 September were classified at "mixed" dates because Microcystis was not concentrated at the surface. The low PC:Chl $a$ ratio on 24 July would indicate that Microcystis was not the dominant phytoplankton on this date, however, large Microcystis colonies were visible and abundant enough on 24 July to collect with plankton net for measurements to be made in the laboratory.

\subsection{Photosynthetic Parameters of Lake Samples}

$\Phi_{\text {et }}$ increased linearly with increasing $k_{d}(p<0.0001)$ for samples collected from both the surface and 1 meter (Figure 4). $\Phi_{\mathrm{et}}$ was greater at 1 meter than surface, due to lower light intensity at 1 meter. Mixing did not have a significant effect on $\Phi_{\text {et }}(p=0.345)$, however, mixing increased $\Phi_{\text {et }}$ at higher $\mathrm{k}_{\mathrm{d}}$ values compared to scum samples. Interactions were not significant $(p=0.551)$.

$F_{\mathrm{v}} / F_{\mathrm{m}}$ of Microcystis was higher when collected when the lake was vertically mixed compared to surface scum (Figure 5(a)). $\mathrm{k}_{\mathrm{d}}$ did not affect $F_{\mathrm{v}} / F_{\mathrm{m}}$ for either mixed $(p$ $\left.=0.11 ; r^{2}=0.196\right)$ or surface scum $\left(p=0.55 ; r^{2}=0.028\right)$ samples. $\mathrm{rETR}_{\max }$ significantly $\left(p=0.0076 ; r^{2}=0.460\right)$ increased with $k_{d}$ when collected during mixing, but was unaffected during surface scum $\left(p=0.40 ; r^{2}=0.060\right)$ 


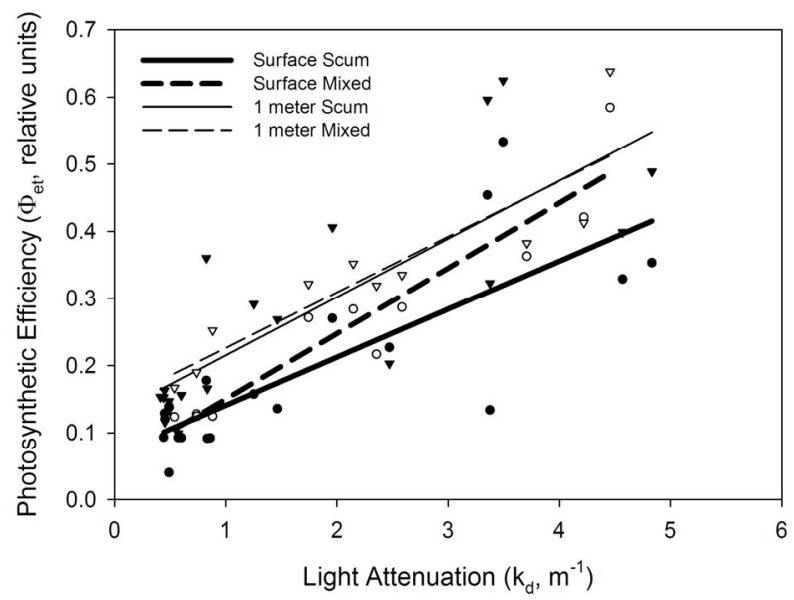

Figure 4. Photosynthetic efficiency $\left(\Phi_{\text {et }}\right)$ measured in western Lake Erie at the surface (thick lines, circles) and at 1 meter depth (thin lines, triangles), and either when surface scum was present (solid lines, filled symbols) or mixed (dashed lines, open symbols) as a function of light attenuation.

(Figure 5(b)). rETR max $_{\text {ax }}$ was greatest at light intensities less than $1044 \mu \mathrm{mol}$ photons $\mathrm{m}^{-2} \cdot \mathrm{s}^{-1}$, thus high light caused photoinhibition, especially at low $\mathrm{k}_{\mathrm{d}}$. On average, $\mathrm{rETR}_{\max }$ for scum samples occurred at $348 \mu \mathrm{mol}$ photons $\mathrm{m}^{-2} \cdot \mathrm{s}^{-1}$, while at $618 \mu \mathrm{mol}$ photons $\mathrm{m}^{-2} \cdot \mathrm{s}^{-1}$ for mixed samples. The ability to maintain photosynthesis under high-light intensity is presented as rETR measured at $1044 \mu \mathrm{mol}$ photons $\mathrm{m}^{-2} \cdot \mathrm{s}^{-1}$ (Figure 5(c)). Mixed samples had rETR at $1044 \mu \mathrm{mol}$ photons $\mathrm{m}^{-2} \cdot \mathrm{s}^{-1}$ that significantly $\left(p=0.0009 ; r^{2}=0.676\right)$ increased with increasing $k_{d}$, while surface scum Microcystis were not affected $(p=$ $\left.0.77 ; r^{2}=0.007\right)$ by $k_{d}$.

\subsection{Pigment Content of Lake Samples}

ANCOVA analysis revealed that sample location did not significantly affect chl $a(p=0.81), \mathrm{PC}(p=0.12)$, and total carotenoid:chl $a(p=0.28)$. Regressions analysis revealed that the chl $a$ linearly increased with increasing $\mathrm{k}_{\mathrm{d}}\left(p=0.0004, r^{2}=0.513\right)$, and PC increased linearly six-fold with increasing $k_{d}\left(p=0.0003, r^{2}=0.526\right)($ Figures 6(a) and (b)). Total carotenoid:chl $a$ decreased with increasing $\mathrm{k}_{\mathrm{d}}\left(p=0.0012, r^{2}=0.450\right)$ (Figure 6(c)). Total carotenoid content ranged from $2.11 \mathrm{mg} \cdot \mathrm{g}^{-1}$ to 3.38 $\mathrm{mg} \cdot \mathrm{g}^{-1}$.

\subsection{Labotory Experiment}

The laboratory photosynthetic efficiency experiment produced results similar to and consistent with the lake study. Suspended sediments significantly $(p<0.0001)$ increased $\Phi_{\mathrm{et}}$ for each treatment combination of mixing and depth (Figure 7(a)). $\Phi_{\text {et }}$ was significantly affected by the depth*mixing interaction $(p<0.0001)$. Nutrients
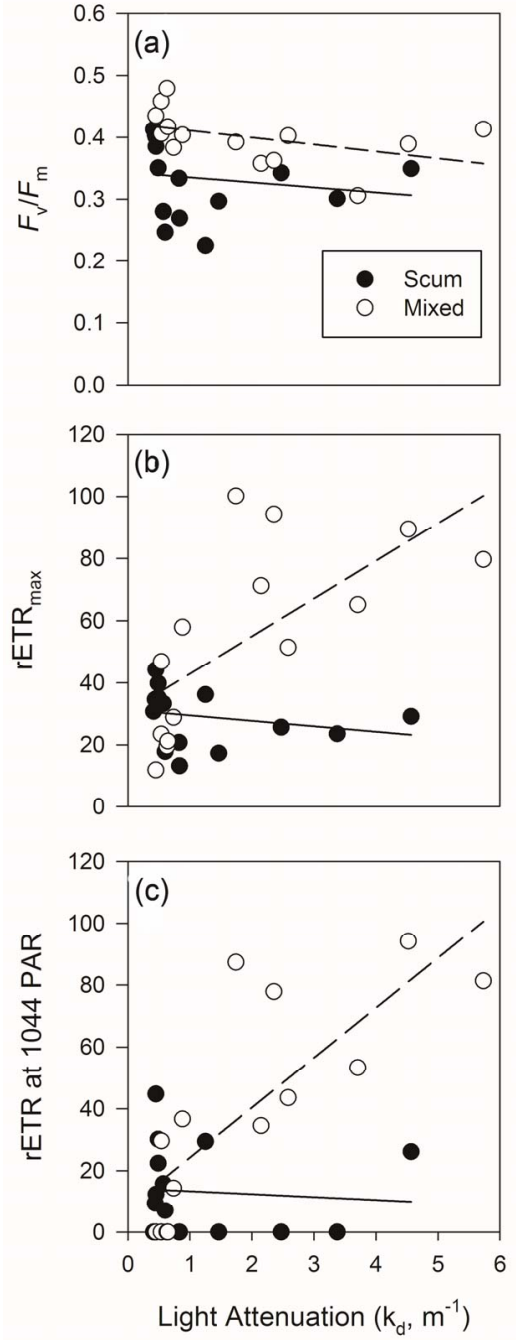

Figure 5. $F_{v} / F_{m}(a)$, maximum relative electron transport rate $\left(\mathrm{rETR}_{\mathrm{max}} ;(\mathrm{b})\right)$, rETR at light intensity $1044 \mu \mathrm{mol}$ photons $\mathrm{m}^{-2} \cdot \mathrm{s}^{-1}$ (c) from light response curves generated in the laboratory from Microcystis collected in western Lake Erie, as a function of in-lake light attenuation.

(high $\mathrm{P}$ and $\mathrm{N}$ vs low $\mathrm{P}$ and $\mathrm{N}$ ) did not have a significant effect on $\Phi_{\text {et }}$, and no other interactions were present $(p>$ $0.5)$. Tukey test showed that $\Phi_{\text {et }}$ was statistically greater $(p<0.05)$ at depth than at the surface for the calm treatment among both suspended sediments levels.

$F_{\mathrm{v}} / F_{\mathrm{m}}$ was significantly affected only by suspended sediments $(p=0.0004) . F_{\mathrm{v}} / F_{\mathrm{m}}$ was greatest in the highsediment treatment (Figure 7(b)). Depth, mixing, nutriaents, or their interactions did not significantly affect $F_{\mathrm{v}} / F_{\mathrm{m}}(p>0.1)$.

The total carotenoid:chl $a$ ratio was only significantly affected by suspended sediments $(p=0.0007)$. Total carotenoid:chl was $0.412 \pm 0.018$ in the low-sediment treatment, and $0.318 \pm 0.013$ in the high-sediment treatment. Total carotenoid:chl $a$ was not affected by any other factors or their interactions $(p>0.4)$. 


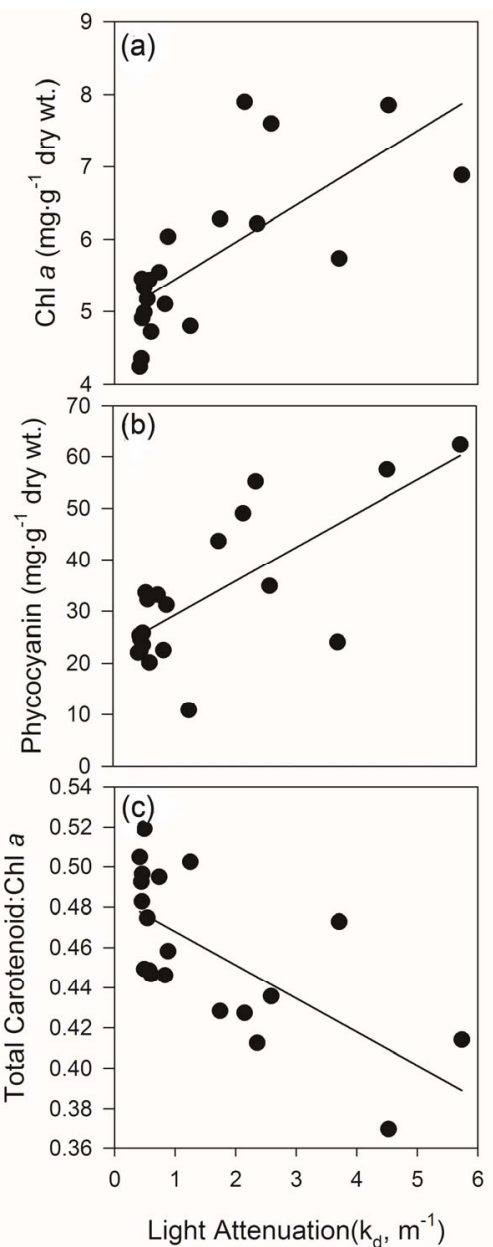

Figure 6. Chl $a$ (a) and phycocyanin (b) content and the ratio of total carotenoid to $\operatorname{chl} \boldsymbol{a}$ (c) of Microcystis collected in western Lake Erie as a function of light attenuation.

\section{Discussion}

\subsection{Sediment Plumes and Moderate Mixing Favor Microcystis}

Our study conducted in western Lake Erie, which receives a heavy suspended sediment load from the Maumee River [14] and lake bottom resuspension [30], demonstrated how sediment plumes increase Microcystis photosynthetic status relative to clear water. Tributaries [13] and resuspension [48] also increase $\mathrm{P}$ concentration of lakes, but here we isolate the effects of suspended sediments and nutrients. $\Phi_{\text {et }}$ measured at the lake surface increased with increasing suspended sediments in both the lake study and laboratory experiment (Figures $\mathbf{4}$ and 7(a)), which indicates increased protection from highlight intensities with increasing suspended sediment concentration. The greater $\Phi_{\text {et }}$ measured at 1 meter is a factor of light attenuation with depth, hence greater $\Phi_{\mathrm{et}}$. The lake $\Phi_{\text {et }}$ samples were community measures, while only Microcystis was used to the laboratory experiment,

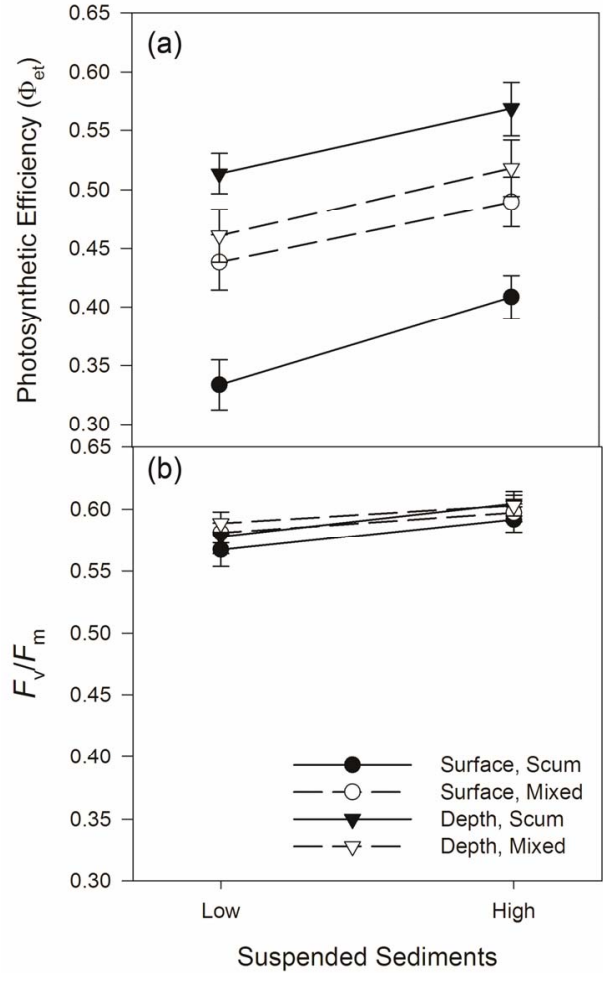

Figure 7. In situ quantum yield of photosystem II electron transport $\left(\Phi_{\mathrm{et}}\right)$ of light-adapted samples (a), and $F_{\mathrm{v}} / \boldsymbol{F}_{\mathrm{m}}$ of dark-adapted samples (b) of Lake Erie Microcystis grown in laboratory conditions under natural sunlight intensities, high or low suspended sediments, and mixing or calm water.

yet they yielded similar results, because Microcystis dominated the lake samples. Therefore, Microcystis (as well as other phytoplankton) at the surface of a lake high in suspended sediments will have greater photosynthetic efficiency than Microcystis at the surface of a clear lake.

Microcystis is able to remain at or near the surface of the lake, which provides a competitive advantage in light-limiting conditions over negatively buoyant phytoplankton [9]. However, this advantage comes at a physiological price. Surface Microcystis scums become damaged, as indicated by the depressed $F_{\mathrm{v}} / F_{\mathrm{m}}$ values compared to mixed water column samples (Figure 5(a)). Data generated from PI curves further support the hypothesis of photosynthetic damage to surface scums because $\mathrm{rETR}_{\max }$ (Figure 5(b)) and the ability to handle high-light intensity (Figure 5(c)) were not affected by $k_{d}$ measured during sample collection. In contrast, the nondamaged samples collected during mixing responded with increasing $\mathrm{rETR}_{\max }$ and increasing rETR at highlight intensity with increasing $\mathrm{k}_{\mathrm{d}}$. However, suspended sediments increased $\Phi_{\mathrm{et}}$ in the surface scum samples in the lake study and laboratory experiment (Figures 4, 7(a)). Thus, the depressed surface $\Phi_{\text {et }}$ values recorded in clear water during the lake study with low $\mathrm{k}_{\mathrm{d}}$ must be a 
result of photo-protective down-regulation, as opposed to further damage, because $F_{\mathrm{v}} / F_{\mathrm{m}}$ did not change with $\mathrm{k}_{\mathrm{d}}$ (Figure 5(a)). In the lake and laboratory study, among surface samples, $\Phi_{\text {et }}$ was greater in mixed-water conditions when compared to calm waters with a surface scum (Figures 4 and 7(a)). Surface scums in the calm water would have a high average light exposure, while average light exposure would be less in a mixed water column. Mixing would transport surface Microcystis and other phytoplankton downward, providing relief from highintensities of light, while upward-mixing exposes phytoplankton that were adapted to low-light levels at depth to high-light intensities near the surface.

Vertical mixing, on the other hand, circulates Microcystis throughout the water column, which decreases exposure to high-light intensities preventing photosynthetic damage. However Microcystis growth stops in strongly-mixed waters $[49,50]$, and the competitive edge is shifted towards negatively buoyant phytoplankton [9]. Microcystis would benefit from moderate winds that break up the surface scum, yet allow it to maintain a relatively higher position in the upper water column than competing species. Microcystis biovolume rapidly increased between 12 August and 21 August (Figure 2). During this time, the median mid-day wind speed measured at Toledo, Ohio was $2.23 \mathrm{~m} \cdot \mathrm{s}^{-1}$ (National Oceanic and Atmospheric Administration, Data Station THRO1 9063085, Toledo, OH, www.ndbc.noaa.gov/station_page. php?station=THRO1). This wind speed would provide the ideal mixing condition for Microcystis, allowing the buoyant Microcystis to maintain position in the upper portion of the water column, but also prevent long-term exposure to direct sunlight.

Reduced $F_{\mathrm{v}} / F_{\mathrm{m}}$ indicates that photo-damage was observed in Microcystis collected from the lake; however, very little damage was seen in the laboratory experiment (Figure 7(b)). This difference could be due to our inability to replicate full-sunlight intensity in the laboratory. In the lake, Microcystis was exposed to full sunlight that exceeded $2000 \mu \mathrm{mol}$ photons $\mathrm{m}^{-2} \cdot \mathrm{s}^{-1}$ PAR at the surface, while the maximum light intensity of the laboratory experiment was around $1400 \mu \mathrm{mol}$ photons $\mathrm{m}^{-2} \cdot \mathrm{s}^{-1} \mathrm{PAR}$ for shorter periods of time. This suggests that Microcystis may become light damaged at intensities between 1400 and $2000 \mu \mathrm{mol}$ photons $\mathrm{m}^{-2} \cdot \mathrm{s}^{-1}$ PAR. UV radiation would also result in damage [39], and greenhouse glass blocks most UV radiation, thus we would have had a reduced UV effect in our experiment.

\subsection{Microcystis Alters Pigment Content}

Care needs to be taken when analyzing cyanobacteria fluorescence data [40], because, unlike higher photosynthetic organisms wherein fluorescence originates only from chlorophyll, PC also provides fluorescence in cyanobacteria. Steady-state fluorescence of light-acclimated and minimum fluorescence of dark-acclimated samples increases with PC content, therefore lowering $\Phi_{\text {et }}$ and $F_{\mathrm{v}} / F_{\mathrm{m}}$ values even if PSII function is not inhibited [40]. We recorded higher PC content in turbid waters. If PSII function was similar between clear water and turbid water, we would expect decreased $\Phi_{\text {et }}$ and $F_{\mathrm{v}} / F_{\mathrm{m}}$ in turbid water due to higher PC content. This was not the case, because $\Phi_{\mathrm{et}}$ and $F_{\mathrm{v}} / F_{\mathrm{m}}$ were greater in turbid water; thus, our pigment data further support our fluorescence data.

Numerous laboratory studies have shown that cyanobacteria grown under different light intensities photoacclimate by altering the amount of the light-harvesting pigments and photo-protective pigments [17,51]. Photoacclimation among phytoplankton in deep stratified lakes has also been shown $[16,52]$. The photosynthetic pigment data presented here indicates that Microcystis alters its pigment content in response to changes in water clarity on spatial and temporal scales in Lake Erie (Figure 6). These results have implications for using pigment concentration as a proxy for phytoplankton biomass, because chl $a$ and PC content vary with water clarity. Therefore pigment concentration may be an inaccurate proxy for algal biomass, especially when comparing turbid-nearshore to less-turbid-offshore waters of large lakes. For example, based on an analysis of PC content alone, the Microcystis biomass in turbid Maumee Bay would likely be overestimated by a factor of six relative to the clearer open waters of the lake. Moreover, PC fluorescence is a new tool to monitor lakes for potential toxin-producing cyanobacteria blooms $[53,54]$. Chl $a$ is less variable than PC with water clarity, but could still result in an overestimation of algal biomass by a factor of two over the range of water clarity conditions observed in our study. On the other hand, researchers utilizing PC fluorescence may overlook potential harmful blooms during the early low-biomass stage of bloom development in clear lakes.

Carotenoids have several functions, acting as lightharvesting pigments and also as photo-protective molecules [52]. Paerl et al. [55] observed a steady increase in total carotenoid:chl $a$ of Microcystis over a summer in the Neuse River (North Carolina, USA) and attributed the high carotenoid content to its survival near the surface of lakes in high intensity sunlight. In contrast, we measured a decrease in Microcystis' carotenoid:chl a ratio throughout the summer of 2008. Our results differ from Paerl et al. [55] because the 2008 Lake Erie Microcystis bloom first appeared during relatively clear water conditions and needed more photo-protective carotenoid pigments. After the water clarity decreased in mid-August, the need for photo-protective pigments decreased and the need for light-harvesting pigments would have increased. 


\subsection{Effect of Nutrients}

In order for phytoplankton to acclimate to different light intensities, nutrients, especially $\mathrm{N}$, needs to be available $[56,57]$, mostly due to the $\mathrm{N}$ demand in the chl $a$ and PC molecules. In a parallel study, Chaffin et al. [27] assessed Microcystis nutrient status via cellular $\mathrm{N}$ and $\mathrm{P}$ content and ratios to carbon $(\mathrm{C})$ and showed that all samples were N-replete and many of samples were moderately deficient in $\mathrm{P}$, but $30 \%$ of the Microcystis had no nutrient deficiency. The content of chl $a$ and PC explained $70 \%$ of the variation in the $\mathrm{N}$ content [27]. Thus, Microcystis had sufficient $\mathrm{N}$ to meet the $\mathrm{N}$ demand required to produce chl $a$ and PC in waters with high concentrations of suspended sediments.

Low nutrient concentrations can exacerbate the effect that high-light has on photoinhibition [58]. Microcystis cultured in low $\mathrm{P}$ concentrations will have decreased rETR values of the PI curve [59]. Furthermore, low nutrient concentrations have been documented to decrease phytoplankton $\Phi_{\text {et }}[60]$ and $F_{\mathrm{v}} / F_{\mathrm{m}}$ [61] including Lake Erie [62]. On the contrary, Harrison [63] showed the nutrient status of phytoplankton did not affect the $F_{\mathrm{v}} / F_{\mathrm{m}}$. In our laboratory experiment nutrients did not affect $F_{\mathrm{v}} / F_{\mathrm{m}}$ or $\Phi_{\text {et }}$, and furthermore, linear regression between $F_{\mathrm{v}} / F_{\mathrm{m}}$ and the $\mathrm{N}$ and $\mathrm{P}$ quota reported in Chaffin et al. [27] resulted in non-significant relationships $(p>0.1)$. Our finding that nutrients did not affect $F_{\mathrm{v}} / F_{\mathrm{m}}$ differs with Rattan et al. [62] who concluded nutrient deficiency would decrease $F_{\mathrm{v}} / F_{\mathrm{m}}$. Rattan et al. [62] collected data in Lake Erie during 2005 and reported that many of their samples had C:N ratios that would indicate a moderate $\mathrm{N}$ deficiency. We conducted our study during 2008 and Microcystis did not have a $\mathrm{N}$ deficiency. Because nutriaent concentration did not affect $\Phi_{\mathrm{et}}$ or $F_{\mathrm{v}} / F_{\mathrm{m}}$ in both the laboratory experiment and the 2008 lake samples, the photoinhibition observed in clear water was not due to lower nutrient concentration, but from lack of protective suspended sediments.

\subsection{Microcystis Abundance}

The increase of suspended sediments during mid August resulted in a light limited water column (Figure 2). Lakes with higher concentrations of suspended sediments often have lower total phytoplankton abundance due to light limitation [4,64]. Microcystis would be less affected by light limitation because of buoyancy regulation [65], which was seen in our study because Microcystis obtained high abundances during light limitation (Figure 2). The data presented here suggest suspended sediments favor Microcystis blooms, although other factors could have contributed to the increase of Microcystis abundance. Sediments and nutrients co-vary in our study site, and the increase of sediments was accompanied by total $\mathrm{P}$ concentrations that increased from $1.61 \mu \mathrm{mol} \cdot \mathrm{L}^{-1}$ to
$2.91 \mu \mathrm{mol} \cdot \mathrm{L}^{-1}$ from July to September [27]. Stratification is important to the success of Microcystis [9]. Low wind speeds during the time Microcystis abundance rapidly increased would have suppressed vertical mixing [32]. Seasonal succession patterns are not evident because water temperature during 2008 was between $22^{\circ} \mathrm{C}$ and $26^{\circ} \mathrm{C}$ (Figure 2), and because the annual bloom can peak at different times of the summer [27]. Non-quantified factors such as grazers removing Microcystis' competetors $[12,66]$ could also have influenced Microcystis abundance patterns.

\section{Conclusion}

The negative impacts of suspended sediments on fish and benthic macroinvertebrates are well known [15]. In this report we show suspended sediments negatively affect eutrophication by providing Microcystis a more favorable light climate for photosynthesis. Western Lake Erie is usually turbid due to high suspended sediment loading from the Maumee River [14,28]. Also, resuspension of lake sediments [30], dredging of the shipping canal, and open water disposal of those dredged sediments increase turbidity. Although resuspension does not affect longterm lake recovery following nutrient reductions [67], resuspension or dredging during a Microcystis blooms will acerbate that bloom. Thus, the effects of suspended sediments should not be ignored when planning lake restoration. Because suspended sediments can be an important factor in promoting buoyant cyanobacteria such as Microcystis, future efforts to reduce blooms may include components aimed at reducing suspended sediments combined with reducing nutrient loading.

\section{Acknowledgements}

The authors would like to thank Dr. Sasmita Mishra for laboratory assistance, Dr. Cyndee Gruden for use of their lab's sonicator, Dr. Mike McKay for a phycocyanin protocol, our team of undergraduates (Jesse Filbrun, Steve Timmons, Catie Wukusick, and Janine Cannell) for assistance collecting data in the field and setting up the laboratory experiments. We thank anonymous reviewers who provided helpful comments. This research was supported by the Ohio Sea Grant College Program, Project R/ER 72, under Grant NA16RG2252 from the National Sea Grant College Program, National Oceanic and Atmospheric Administration and by funds provided by the Lake Erie Commission, Lake Erie Protection Fund Project \#0-08. This is contribution number 2012-14 of the Lake Erie Center.

\section{REFERENCES}

[1] V. H. Smith, S. B. Joye and R. W. Howarth, "Eutrophication of Freshwater and Marine Ecosystems," Limnology 
and Oceanography, Vol. 51, No. 1, 2006, pp. 351-355. doi:10.4319/10.2006.51.1 part 2.0351

[2] J. Huisman, H. C. P. Matthijs and P. M. Visser, "Harmful Cyanobacteria," Kluwer Academic Publisher, Dordrecht, 2005. doi:10.1007/1-4020-3022-3

[3] W. K. Dodds, W. W. Bouska, J. L. Eitzmann, T. J. Pilger, K. L. Pitts, A. J. Riley, J. T. Schloesser and D. J. Thornbrugh, "Eutrophication of US Freshwaters: Analysis of Potential Economic Damages," Environmental Science \& Technology, Vol. 43, No. 1, 2008, pp. 12-19. doi: $10.1021 / \mathrm{es} 801217 \mathrm{q}$

[4] V. H. Smith, "Eutrophication of Freshwater and Coastal Marine Ecosystems: A Global Problem," Environmental Science and Pollution Research, Vol. 10, No. 2, 2003, pp. 126-139. doi:10.1065/espr2002.12.142

[5] N. P. Holm and D. E. Armstrong, "Role of Nutrient Limitation and Competition in Controlling the Populations of Asterionella formosa and Microcystis aeruginosa in Semicontinuous Culture," Limnology and Oceanography, Vol. 26, No. 4, 1981, pp. 622-634. doi:10.4319/lo.1981.26.4.0622

[6] J. A. Downing, S. B. Watson and E. McCauley, "Predicting Cyanobacteria Dominance in Lakes," Canadian Journal of Fisheries and Aquatic Sciences, Vol. 58, No. 10, 2001, pp. 1905-1908. doi:10.1139/f01-143

[7] V. H. Smith, "Low Nitrogen to Phosphorus Ratios Favor Dominance by Blue-Green Algae in Lake Phytoplankton," Science, Vol. 221, No. 4611, 1983, pp. 669-671. doi:10.1126/science.221.4611.669

[8] P. M. Visser, B. W. Ibelings, B. Vanderveer, J. Koedood and L. R. Mur, "Artificial Mixing Prevents Nuisance Blooms of the Cyanobacterium Microcystis in Lake Nieuwe Meer," Freshwater Biology, Vol. 36, No. 2, 1996, pp. 435-450. doi:10.1046/j.1365-2427.1996.00093.x

[9] J. Huisman, J. Sharples, J. M. Stroom, P. M. Visser, W. E. A. Kardinaal, J. M. H. Verspagen and B. Sommeijer, "Changes in Turbulent Mixing Shift Competition for Light between Phytoplankton Species," Ecology, Vol. 85, No. 11, 2004, pp. 2960-2970. doi:10.1890/03-0763

[10] K. D. Jöhnk, J. Huisman, J. Sharples, B. Sommeijer, P. M. Visser and J. M. Stroom, "Summer Heatwaves Promote Blooms of Harmful Cyanobacteria," Global Change Biology. Vol. 14, No. 3, 2008, pp. 495-512. doi:10.1111/j.1365-2486.2007.01510.x

[11] H. W. Paerl and J. Huisman, "Blooms Like It Hot," Science, Vol. 320, No. 5872, 2008, pp. 57-58. doi:10.1126/science. 1155398

[12] H. A. Vanderploeg, J. R. Liebig, W. W. Carmichael, M. A. Agy, T. H. Johengen, G. L. Fahnenstiel and T. F. Nalepa, "Zebra Mussel (Dreissena polymorpha) Selective Filtration Promoted Toxic Microcystis Blooms in Saginaw Bay (Lake Huron) and Lake Erie," Canadian Journal of Fisheries and Aquatic Sciences, Vol. 58, No. 6, 2001, pp. 1208-1221. doi:10.1139/f01-066

[13] D. B. Baker and R. P. Richards, "Phosphorus Budgets and Riverine Phosphorus Export in Northwestern Ohio Watersheds," Journal of Environmental Quality, Vol. 31, No. 1, 2002, pp. 96-108. doi:10.2134/jeq2002.0096
[14] R. P. Richards, D. B. Baker, J. P. Crumrine, J. W. Kramer, D. E. Ewing and B. J. Merryfield, "Thirty-Year Trends in Suspended Sediment in Seven Lake Erie Tributaries," Journal of Environmental Quality, Vol. 37, No. 5, 2008, pp. 1894-1908. doi:10.2134/jeq2007.0590

[15] I. Donohue and J. Garcia Molinos, "Impacts of Increased Sediment Loads on the Ecology of Lakes," Biological Reviews, Vol. 84, No. 4, 2009, pp. 517-531. doi:10.1111/j.1469-185X.2009.00081.x

[16] J. T. O. Kirk, "Light and Photosynthesis in Aquatic Ecosystems," 2nd Edition, Cambridge University Press, Canberra, 1994. doi:10.1017/CBO9780511623370

[17] H. L. MacIntyre, T. M. Kana, T. Anning and R. J. Geider, "Photoacclimation of Photosynthesis Irradiance Response Curves and Photosynthetic Pigments in Microalgae and Cyanobacteria," Journal of Phycology, Vol. 38, No. 1, 2002, pp. 17-38. doi:10.1046/j.1529-8817.2002.00094.x

[18] A. E. Alpine and J. E. Cloern, "Phytoplankton Growth Rates in a Light-Limited Environment, San Francisco Bay," Marine Ecology-Progress Series, Vol. 44, No. 2, 1988, pp. 167-173. doi:10.3354/meps044167

[19] P. A. Soranno, "Factors Affecting the Timing of Surface Scum and Epilimnetic Blooms of Blue-Green Algae in a Eutrophic Lake," Canadian Journal of Fisheries and Aquatic Sciences, Vol. 54, No. 9, 1997, pp. 1965-1975. doi:10.1139/cjfas-54-9-1965

[20] B. W. Ibelings and S. C. Maberly, "Photoinhibition and the Availability of Inorganic Carbon Restrict Photosynthesis by Surface Blooms of Cyanobacteria," Limnology and Oceanography, Vol. 43, No. 3, 1998, pp. 408-419. doi:10.4319/10.1998.43.3.0408

[21] J. Huisman, P. van Oostveen and F. J. Weissing, "Critical Depth and Critical Turbulence: Two Different Mechanisms for the Development of Phytoplankton Blooms," Limnology and Oceanography, Vol. 44, No. 7, 1999, pp. 17811787. doi:10.4319/10.1999.44.7.1781

[22] I. T. Webster and P. A. Hutchinson, "Effect of Wind on the Distribution of Phytoplankton Cells in Lakes Revisited," Limnology and Oceanography, Vol. 39, No. 2, 1994, pp. 365-373. doi:10.4319/1o.1994.39.2.0365

[23] P. M. Visser, B. W. Ibelings, L. R. Mur and A. E. Walsby, "The Ecophysiology of the Harmful Cyanobacterium Microcystis," In: J. Huisman, H. C. P. Matthijs and P. M. Visser, Eds., Harmful Cyanobacteria, Kluwer Academic Publisher, Dordrecht, 2005, pp. 109-142. doi:10.1007/1-4020-3022-3_6

[24] B. W. Ibelings, B. M. A. Kroon and L. R. Mur, "Acclimation of Photosystem II in a Cyanobacterium and a Eukaryotic Green Alga to High and Fluctuating Photosynthetic Photon Flux Densities, Simulating Light Regimes Induced by Mixing in Lakes," New Phytologist, Vol. 128, No. 3, 1994, pp. 407-424. doi:10.1111/j.1469-8137.1994.tb02987.x

[25] J. D. Brookes, R. H. Regel and G. G. Ganf, "Changes in the Photo-Chemistry of Microcystis aeruginosa in Response to Light and Mixing," New Phytologist, Vol. 158, No. 1, 2003, pp. 151-164. doi:10.1046/j.1469-8137.2003.00718.x

[26] T. H. Johengen, B. A. Biddanda and J. B. Cotner, "Stimulation of Lake Michigan Plankton Metabolism by 
Sediment Resuspension and River Runoff," Journal of Great Lakes Research, Vol. 34, No. 2, 2008, pp. 213-227. doi:10.3394/0380-1330(2008)34[213:SOLMPM]2.0.CO;2

[27] J. D. Chaffin, T. B. Bridgeman, S. A. Heckathorn and S. Mishra, "Assessment of Microcystis Growth Rate Potential and Nutrient Status Across a Trophic Gradient in Western Lake Erie," Journal of Great Lakes Research, Vol. 37, No. 1, 2011, pp. 92-100. doi:10.1016/j.jglr.2010.11.016

[28] B. Binding, G. Greenberg and B. Bukata, "An Analysis of MODIS-Derived Algal and Mineral Turbidity in Lake Erie," Journal of Great Lakes Research, Vol. 38, No. 1, 2012, pp. 107-116. doi:10.1016/j.jglr.2011.12.003

[29] H. Han, N. Bosch and J. D. Allan, "Spatial and Temporal Variation in Phosphorus Budgets for 24 Watersheds in the Lake Erie and Lake Michigan Basins," Biogeochemistry, Vol. 102, No. 1-3, 2011, pp. 45-58. doi:10.1007/s10533-010-9420-y

[30] F. Peng and S. W. Effler, "Characterizations of Individual Suspended Mineral Particles in Western Lake Erie: Implications for Light Scattering and Water Clarity," Journal of Great Lakes Research, Vol. 36, No. 4, 2010, pp. 686-698. doi:10.1016/j.jglr.2010.08.003

[31] J. D. Ackerman, M. R. Loewen and P. F. Hamblin, "Benthic-Pelagic Coupling over a Zebra Mussel Reef in Western Lake Erie," Limnology and Oceanography, Vol. 46, No. 4, 2001, pp. 892-904. doi:10.4319/10.2001.46.4.0892

[32] L. Boegman, M. R. Loewen, P. F. Hamblin and D. A. Culver, "Vertical Mixing and Weak Stratification over Zebra Mussel Colonies in Western Lake Erie," Limnology and Oceanography, Vol. 53, No. 3, 2008, pp. 1093-1110. doi: $10.4319 / 10.2008 .53 .3 .1093$

[33] T. B. Bridgeman, D. W. Schloesser and A. E. Krause, "Recruitment of Hexagenia Mayfly Nymphs in Western Lake Erie Linked to Environmental Variability," Ecological Applications, Vol. 16, No. 2, 2006, pp. 601-611. doi:10.1890/1051-0761(2006)016[0601:ROHMNI]2.0.CO;2

[34] D. Moorhead, T. Bridgeman and J. Morris, "Changes in Water Quality of Maumee Bay 1928-2003," In: M. Munawar and R. Heath, Eds., Checking the Pulse of Lake Erie, Goodword Books, Baltimore, 2008, pp.123-158.

[35] D. F. Millie, G. L. Fahnenstiel, J. Dyble Bressie, R. J. Pigg, R. R. Rediske, D. M. Klarer, P. A. Tester and R. W. Litaker, "Late-Summer Phytoplankton in Western Lake Erie (Laurentian Great Lakes): Bloom Distributions, Toxicity, and Environmental Influences," Aquatic Ecology, Vol. 43, No. 4, 2009, pp. 915-934. doi:10.1007/s10452-009-9238-7

[36] K. Maxwell and G. N. Johnson, "Chlorophyll Fluorescence-A Practical Guide," Journal of Experimental Botany, Vol. 51, No. 345, 2000, pp. 659-668. doi:10.1093/jexbot $/ 51.345 .659$

[37] G. H. Krause, "Photoinhibition of Photosynthesis. An Evaluation of Damaging and Protective Mechanisms," Physiologia Plantarum, Vol. 74, No. 566-574, 1988, pp. 566-574. doi:10.1111/j.1399-3054.1988.tb02020.x

[38] B. Genty, J. M. Briantais and N. R. Baker, "The Relationship Between the Quantum Yield of Photosynthetic Electron Transport and Quenching of Chlorophyll Fluorescence,"
Biochimica et Biophysica Acta, Vol. 990, No. 1, 1989, pp. 87-92. doi:10.1016/S0304-4165(89)80016-9

[39] C. A. Marwood, R. E. H. Smith, J. A. Furgal, M. N. Charlton, K. R. Solomon and B. M. Greenberg, "Photoinhibition of Natural Phytoplankton Assemblages in Lake Erie Exposed to Solar Ultraviolet Radiation," Canadian Journal of Fisheries and Aquatic Sciences, Vol. 57, No. 2, 2000, pp. 371-379. doi:10.1139/f99-258

[40] D. Campbell, V. Hurry, A. K. Clarke, P. Gustafsson and G. Oquist, "Chlorophyll Fluorescence Analysis of Cyanobacterial Photosynthesis and Acclimation," Microbiology and Molecular Biology Reviews, Vol. 62, No. 3, 1998, pp. 667-683.

[41] S. A. Heckathorn, S. L. Ryan, J. A. Baylis, D. Wang, E. W. Hamilton, L. Cundiff and D. S. Luthe, "In Vivo Evidence From an Agrostis stolonifera Selection Genotype That Chloroplast Small Heat-Shock Proteins can Protect Photosystem II During Heat Stress," Functional Plant Biology, Vol. 29, No. 8, 2002, pp. 933-944. doi:10.1071/PP01191

[42] U. Schreiber, W. Bilger and C. Neubauer, "Chlorophyll Fluorescence as a Nonintrusive Indicator for Rapid Assessment of in Vivo Photosynthesis," In: E. Schulze and M. M. Caldwell, Eds., Ecophysiology of Photosynthesis, SpringerVerlag, Berlin, 1994, pp. 49-70.

[43] M. Zhang, X. Shi, Y. Yu and F. Kong, "The Acclimative Changes in Photochemistry After Colony Formation of the Cyanobacteria Microcystis aeruginosa," Journal of Phycology, Vol. 47, No. 3, 2011, pp. 524-532. doi:10.1111/j.1529-8817.2011.00987.x

[44] A. R. Wellburn, "The Spectral Determination of Chlorophyll $a$ and Chlorophyll $b$, as well as Total Carotenoids, Using Various Solvents with Spectrophotometers of Different Resolution," Journal of Plant Physiology, Vol. 144, No. 3, 1994, pp. 307-313. doi:10.1016/S0176-1617(11)81192-2

[45] P. Sampath-Wiley and C. D. Neefus, "An Improved Method for Estimating R-Phycoerythrin and R-Phycocyanin Contents from Crude Aqueous Extracts of Porphyra (Bangiales, Rhodophyta)," Journal of Applied Phycology, Vol. 19, No. 2, 2007, pp. 123-129. doi:10.1007/s10811-006-9118-7

[46] R. R. L. Guillard and C. J. Lorenzen, "Yellow-Green Algae with Chlorophyllide c," Journal of Phycology, Vol. 8, No. 1, 1972, pp. 10-14. doi:10.1111/j.1529-8817.1972.tb03995.x

[47] M. H. Kutner, C. J. Nachtsheim, J. Neter and W. Li, “Applied Linear Statistical Model," 5th Edition, McGraw-Hill/ Irwin, New York, 2004.

[48] M. Søndergaard, P. Kristensen and E. Jeppesen, "Phosphorus Release from Resuspended Sediment in the Shallow and Wind-Exposed Lake Arreso, Denmark," Hydrobiologia, Vol. 228, No. 1, 1992, pp. 91-99. doi:10.1007/BF00006480

[49] C. S. Reynolds, S. W. Wiseman and M. J. O. Clarke, "Growth-and Loss-Rate Responses of Phytolankton to Intermittent Artificial Mixing and their Potential Application to the Control of Planktonic Algal Biomass," Journal of Applied Ecology, Vol. 21, No. 1, 1984, pp. 11-39. doi: $10.2307 / 2403035$

[50] J. Köhler, "Influence of Turbulent Mixing on Growth and 
Primary Production of Microcystis aeruginosa in the Hypertrophic Bautzen Reservoir," Archiv Für Hydrobiologie, Vol. 123, No. 4, 1992, pp. 413-429.

[51] M. Schagerl and B. Müller, "Acclimation of Chlorophyll a and Carotenoid Levels to Different Irradiances in Four Freshwater Cyanobacteria," Journal of Plant Physiology, Vol. 163, No. 7, 2006, pp. 709-716. doi:10.1016/j.jplph.2005.09.015

[52] Z. Dubinsky and N. Stambler, "Photoacclimation Processes in Phytoplankton: Mechanisms, Consequences, and Applications," Aquatic Microbial Ecology, Vol. 56, No. 2-3, 2009, pp. 163-176. doi:10.3354/ame01345

[53] K. Izydorczyk, M. Tarczynska, T. Jurczak, J. Mrowczynski and M. Zalewski, "Measurement of Phycocyanin Fluorescenceas an Online Early Warning System for Cyanobacteria in Reservoir Intake Water," Environmental Toxicology, Vol. 20, No. 4, 2005, pp. 425-430. doi:10.1002/tox.20128

[54] N. McQuaid, A. Zamyadi, M. Prévost, D. F. Bird and S. Dorner, "Use of in Vivo Phycocyanin Fluorescence to Monitor Potential Microcystin-Producing Cyanobacterial Biovolume in a Drinking Water Source," Journal of Environmental Monitoring, Vol. 13, No. 2, 2010, pp. 455-463. doi:10.1039/c0em00163e

[55] H. W. Paerl, J. Tucker and P. T. Bland, "Carotenoid Enhancement and Its Role in Maintaining Blue-Green Algal (Microcystis Aeruginosa) Surface Blooms," Limnology and Oceanography, Vol. 28, No. 5, 1983, pp. 847-857. doi:10.4319/1o.1983.28.5.0847

[56] R. J. Geider, H. L. MacIntyre and T. M. Kana, "A Dynamic Regulatory Model of Phytoplanktonic Acclimation to Light, Nutrients, and Temperature," Limnology and Oceanography, Vol. 43, No. 4, 1998, pp. 679-694. doi:10.4319/10.1998.43.4.0679

[57] P. A. Staehr, P. Henriksen and S. Markager, "Photoacclimation of Four Marine Phytoplankton Species to Irradiance and Nutrient Availability," Marine Ecology Progress Series, Vol. 238, 2002, pp. 47-59. doi: $10.3354 / \mathrm{meps} 238047$

[58] S. P. Long, S. Humphries and P. G. Falkowski, "Photoinhibition of Photosynthesis in Nature," Annual Review of Plant Physiology and Plant Molecular Biology, Vol. 45, No. 1, 1994, pp. 633-662. doi:10.1146/annurev.pp.45.060194.003221

[59] Z. C. Wang, D. H. Li, G. W. Li and Y. D. Liu, "Mechanism of Photosynthetic Response in Microcystis aeruginosa PCC-
7806 to Low Inorganic Phosphorus," Harmful Algae, Vol. 9, No. 6, 2010, pp. 613-619. doi:10.1016/i.hal.2010.04.012

[60] K. Stehfest, J. Toepel and C. Wilhelm, "The Application of Micro-FTIR Spectroscopy to Analyze Nutrient StressRelated Changes in Biomass Composition of Phytoplankton Algae," Plant Physiology and Biochemistry, Vol. 43, No. 7, 2005, pp. 717-726. doi:10.1016/j.plaphy.2005.07.001

[61] J. Beardall, E. Young and S. Roberts, "Approaches for Determining Phytoplankton Nutrient Limitation," Aquatic Sciences, Vol. 63, No. 1, 2001, pp. 44-69. doi:10.1007/PL00001344

[62] K. J. Rattan, W. D. Taylor, R. E. H. Smith and G. Weyhenmeyer, "Nutrient Status of Phytoplankton across a Trophic Gradient in Lake Erie: Evidence from New Fluorescence Methods," Canadian Journal of Fisheries and Aquatic Sciences, Vol. 69, No. 1, 2012, pp. 94-111. doi:10.1139/f2011-135

[63] J. Harrison, "Effect of Nutrients, Photoinhibition \& Photoacclimation on Photosystem II Function of Freshwater Phytoplankton Communities," 2011. http://uwspace.uwaterloo.ca/handle/10012/6414

[64] M. V. Hoyer and J. R. Jones, "Factors Affecting the Relation between Phosphorus and Chlorophyll a in Midwestern Reservoirs," Canadian Journal of Fisheries and Aquatic Sciences, Vol. 40, No. 2, 1983, pp. 192-199. doi:10.1139/f83-029

[65] C. S. Reynolds, R. L. Oliver and A. E. Walsby, "Cyanobacterial Dominance: The Role of Buoyancy Regulation in Dynamic Lake Environments," New Zealand Journal of Marine and Freshwater Research, Vol. 21, No. 3, 1987, pp. 379-390. doi:10.1080/00288330.1987.9516234

[66] X. Wang, B. Qin, G. Gao and H. W. Paerl, "Nutrient Enrichment and Selective Predation by Zooplankton Promote Microcystis (Cyanobacteria) Bloom Formation," Journal of Plankton Research, Vol. 32, No. 4, 2010, pp. 457-470. doi:10.1093/plankt/fbp143

[67] E. Jeppesen, J. P. Jensen, M. Søndergaard, K. S. Hansen, P. H. Møller, H. U. Rasmussen, V. Norby and S. E. Larsen, "Does Resuspension Prevent a Shift to a Clear State in Shallow Lakes During Reoligotrophication?" Limnology and Oceanography, 2003, Vol. 48, No. 5, pp. 1913-1919. doi:10.4319/10.2003.48.5.1913 